University of Thi-Qar Journal Vol.12 No.2 June 2017

Web Site: https://jutq.utq.edu.iq/index.php/main

Email: journal@jutq.utq.edu.iq

\title{
DESIGN OF A COMPOSITE FLYWHEEL WITH SPECIFIC REQUIRMENTS
}

https://doi.org/10.32792/utq/utj/vol12/2/4

\section{SAAD JABBR NAZAL \\ COLLEGE OF ENGINEERING /UNIVERSITY OF \\ THI-QAR \\ Saad.alsreefi@gmail.com}

\section{ABSTRACT}

In order to meet the increasing demand of high energy density and long life of energy storage systems, improvement of composite flywheel design approaches have been under development. The goal of this research is to design a flywheel capable of storing 10M-Joules with a mass of $10 \mathrm{Kg}$, a maximum diameter of $750 \mathrm{~mm}$, and a maximum length of $300 \mathrm{~mm}$, while spinning at a nominal speed of 70,000 RPM.

Composite technology is one of the ways to attain extraordinarily high strength-to-weight ratios required for maximum flywheel performance. This report presents a Composite Stodola flywheel design capable of producing 10 M-Joules, with a mass of $10 \mathrm{Kg}$.

The research was conducted to obtain a high quality flywheel for energy storage operations. Elastic, viscoelastic, and fatigue analysis were developed in the design as well as the prediction of the behavior of flywheel.

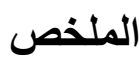

من اجل تلبية الطلب المتزايد على نظام خزن طاقة بطاقة عالية وعمر طويل , فان نظريات تحسين

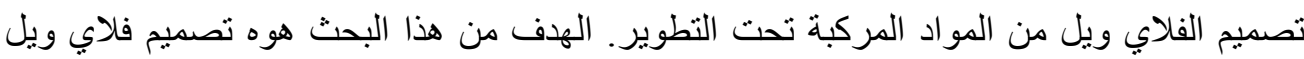




$$
\begin{aligned}
& \text { قادرة على خزن } 10 \text { ميكا جول وبكتلة } 10 \text { كغم وقطر } 750 \text { مم وطول } 300 \text { ملم بينما تدور بسرعة } \\
& \text { قدر ها } 70000 \text { دورة بالدقيقة. } \\
& \text { تكنلوجيا المو اد المركبة هي احدى طرق الحصول على نسب القوة الى الوزن عالية بصورة استثنائية } \\
& \text { و المطلوب تحقيقها من عمل الفلاي ويل. هذا البحث يقدم تصميم ال ستودو لا فلاي ويل قادرة على } \\
& \text { خزن } 10 \text { ميكا جول من الطاقة وبكتلة } 10 \text { كغم. } \\
& \text { البحث يهدف للحصول فلاي ويل بجودة عالية من ناحية عملية خزن الطاقة. يتضمن البحث تحليل } \\
& \text { المرونة والكلل بالاضافة الى التنبؤ بسلوك عمل الفلاي ويل. }
\end{aligned}
$$

\section{INTRODUCTION}

A high-speed flywheel design permits the generation of greater power density than that of chemical batteries. Choosing composite material for the construction of the flywheel will allow the flywheel to achieve the necessary high strength-to-weight ratio and specific energy needed to compete with chemical batteries.

High speed is preferred because a smaller mass moment of inertia, and thus diameter, may be used to store the same amount of energy. The ability of generating more power is a big advantage of flywheel, allowing its use in vehicles where a large power capacity is needed during acceleration and regenerative braking. This facilitates more efficient management of energy, reducing the consumption of fuel.

Since that the aim of this research is to design a reliable flywheel capable of storing $10 \mathrm{M}-J$ oules, the Stodola geometry was used in order to optimize the distribution of stress and thus the safety of the flywheel at high energy levels.

The ideal Stodola profile of a tapered-thickness, infinite-radius flywheel was discovered by engineers of De Laval Company, Sweden circa 1900. The 
Stodola optimization was first published in English in 1927 in the book Steam and Gas Turbines by Aurel Stodola. [1]

In order to get a high mechanical performance flywheel, lamina architecture was proposed in the design. The design and test procedures used in the research were conducted under the consideration of the long-term behavior of flywheel such as creep, stress relaxation, fatigue, and fracture of composites.

\section{CONCEPTUAL DESIGN \& SELECTED OPTIONS}

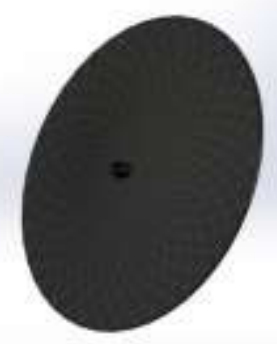

Figure 1: Stodola Flywheel Design

\begin{tabular}{|c|c|c|c|}
\hline Configuration & $r(\mathrm{~mm})$ & $\mathrm{t}(\mathrm{mm})$ & $\mathrm{y}(\mathrm{r})$ \\
\hline T1000/HDPE & 300.00 & 55.25 & \multirow{2}{*}{$\mathrm{y}(r)=t(r)=\frac{t}{2} e^{\frac{-\rho \sigma^{2} \gamma^{2}}{2 \sigma}}$} \\
\hline IM6/HDPE & 300.00 & 56.26 & \\
\hline 2800 Maraging Steel & 200.00 & 10.69 & \\
\hline
\end{tabular}

Table 1: Stodola flywheel Selected Configurations

\begin{tabular}{|c|c|c|c|c|c|}
\hline Configuration & $\begin{array}{c}\sigma_{\text {MAX-FEA }} \\
(\mathrm{Mpa})\end{array}$ & $\begin{array}{c}\sigma_{\mathrm{ULT}} \\
(\mathrm{Mpa})\end{array}$ & $\begin{array}{c}\text { Mass } \\
(\mathrm{Kg})\end{array}$ & $\begin{array}{c}\text { Energy }(\mathrm{M} \\
\text { Joules })\end{array}$ & $\begin{array}{c}\text { FoS } \\
\text { FE }\end{array}$ \\
\hline T1000/HDPE & 1431.14 & 2558.84 & 10.00 & 10.00 & 1.79 \\
\hline IM6/HDPE & 1436.20 & 2083.92 & 10.00 & 10.00 & 1.45 \\
\hline $\begin{array}{c}2800 \text { Maraging } \\
\text { Steel }\end{array}$ & 5265.90 & 2617.00 & 6.69 & 10.00 & 0.50 \\
\hline
\end{tabular}

Table 2: Stodola Flywheel Selected Configurations Performance 
Design Requirements:

-Mass: $10 \mathrm{~kg}$

-Capacity: $10 \mathrm{MJ}$

(Not Alloy)

-RPM: 70,000 RPM = 7,330.4 radians/sec

-Moment of

Inertia $=0.3722 \mathrm{~kg}-\mathrm{m}^{2}$

\begin{tabular}{|c|c|c|c|}
\hline $\begin{array}{c}\text { Flywheel } \\
\text { Material }\end{array}$ & $\begin{array}{c}\text { T1000G/HDP } \\
\mathrm{E}\end{array}$ & $\begin{array}{c}\text { Hexcel } \\
\text { IM6/HDPE }\end{array}$ & $\begin{array}{c}2800 \text { Maraging } \\
\text { Steel }\end{array}$ \\
\hline$\rho\left(\mathrm{Kg} / \mathrm{m}^{3}\right)$ & 1548.0 & 1520.0 & 8000 \\
\hline $\mathrm{F}_{\mathrm{tu}}(\mathrm{MPa})$ & 2558.84 & 2083.92 & 2617 \\
\hline $\begin{array}{c}\text { Specific } \\
\text { Strength } \\
(\mathrm{MJ} / \mathrm{Kg})\end{array}$ & 1.7 & 1.4 & 0.33 \\
\hline $\begin{array}{c}\text { Cutoff Radius, } \\
\mathrm{r}_{\text {max }}(\mathrm{mm})\end{array}$ & 300 & 300 & 200 \\
\hline
\end{tabular}

Table 3; Selected Material Comparison

2800 Maraging Steel alloy flywheels are most feasible to manufacture the flywheel (Table 4).

\begin{tabular}{|c|c|c|c|c|c|}
\hline $\begin{array}{c}\text { Isotropic } \\
\text { material }\end{array}$ & $\begin{array}{c}\text { Price } \\
(\$ / \mathrm{kg})\end{array}$ & $\begin{array}{c}\text { Yield } \\
\text { strength } \\
(\mathrm{MPa})\end{array}$ & $\begin{array}{c}\text { Elastic } \\
\text { Modulus } \\
(\mathrm{GPa})\end{array}$ & $\begin{array}{c}\text { Density } \\
\left(\mathrm{g} / \mathrm{cm}^{3}\right)\end{array}$ & $\begin{array}{c}\text { Poisson's } \\
\text { ratio }\end{array}$ \\
\hline $\begin{array}{c}2800 \\
\text { Maraging } \\
\text { Steel }\end{array}$ & 4 & 2617 & 210 & 8.0 & 0.3 \\
\hline
\end{tabular}

Table 4: Isotropic material cost and properties

\begin{tabular}{|c|c|c|c|c|c|}
\hline Fibers & $\begin{array}{c}\text { Price } \\
(\$ / \mathrm{kg})\end{array}$ & $\begin{array}{c}\text { Yield } \\
\text { strength } \\
(\mathrm{GPa})\end{array}$ & $\begin{array}{c}\text { Elastic } \\
\text { Modulus } \\
(\mathrm{GPa})\end{array}$ & $\begin{array}{c}\text { Density } \\
\left(\mathrm{g} / \mathrm{cm}^{3}\right)\end{array}$ & $\begin{array}{c}\text { Poisson's } \\
\text { ratio }\end{array}$ \\
\hline $\begin{array}{c}\text { Torayca } \\
\text { T1000 }\end{array}$ & $\begin{array}{c}400- \\
500\end{array}$ & $6.3-7.06$ & 294 & 1.8 & 0.2 \\
\hline $\begin{array}{c}\text { Hexcel } \\
\text { IM6 }\end{array}$ & $\begin{array}{c}110- \\
130\end{array}$ & 5.74 & 279 & 1.76 & 0.2 \\
\hline
\end{tabular}

Table 5: Fiber material cost and properties 


\begin{tabular}{|c|c|c|c|c|c|}
\hline Matrices & $\begin{array}{c}\text { Price } \\
(\$ / \mathrm{kg})\end{array}$ & $\begin{array}{c}\text { Service } \\
\text { Temperature } \\
\text { up to }\left({ }^{\circ} \mathrm{C}\right)\end{array}$ & $\begin{array}{c}\text { Elastic } \\
\text { Modulus } \\
(\mathrm{GPa})\end{array}$ & $\begin{array}{c}\text { Density } \\
\left(\mathrm{g} / \mathrm{cm}^{3}\right)\end{array}$ & $\begin{array}{c}\text { Poisson's } \\
\text { ratio }\end{array}$ \\
\hline $\begin{array}{c}\text { Hexply } \\
8552 \\
\text { epoxy }\end{array}$ & $\begin{array}{c}30- \\
40\end{array}$ & 121 & 4.667 & 1.301 & .38 \\
\hline HDPE & $\begin{array}{c}2.2- \\
2.4\end{array}$ & 120 & $\begin{array}{c}1.06- \\
1.09\end{array}$ & $0.93-0.97$ & .2 \\
\hline
\end{tabular}

Table 6: Matrix material cost and properties

\section{ANALYSIS \& DESIGN REQUIREMENTS}

In order to meet the design requirements, the Stodola concept was elected for the design of the flywheel. One of the biggest benefits of utilizing the Stodola concept, is that the principal tensile stresses are equal and constant $\left(\sigma_{\mathrm{r}}=\sigma_{\Theta}=\right.$ $\sigma)$. [3] The project design requirements are as follows:

1. Rotational Speed $=70,000 \mathrm{RPM}$

2. Energy Storage $=10 \mathrm{M}$ Joules

3. Diameter $=750 \mathrm{~mm}$

4. Length $=300 \mathrm{~mm}$

5. Mass $=10 \mathrm{Kg}$

The analysis herein will illustrate a number of options for the proposed design, using different fibers and matrices, as well as an alloy option. Each of the proposed design options will be evaluated for compliance of the design requirements.

Prior to initiating the design analysis, there are some parameters that require definition in order to analyze each of the proposed options. Below is a list of the aforementioned parameters along with their respective mathematical derivations: 
1. $\underline{\text { Root Thickness: }} \quad V=\int 2 \pi r t(r) d r$

Where $t(r)$ is defined using equation (4) of Reference (3)

$$
\begin{aligned}
& { }^{[1]} t(r)=t_{o} e^{\frac{-\rho \omega^{2} r^{2}}{2 \sigma}} \\
& \therefore V=2 \pi t_{0} \int r e^{\frac{-\rho \omega^{2} r^{2}}{2 \sigma}} d r \\
& m=\rho V=\frac{2 \pi r t_{o} \sigma}{\omega^{2}} \\
& \therefore t_{o}=\frac{m \omega^{2}}{2 \pi \sigma}
\end{aligned}
$$

2. Mass Moment of Inertia

$$
\begin{aligned}
& I_{m}=\int r^{2} d m \Rightarrow d m=\rho d V \Rightarrow d V=2 \pi r t(r) d r \\
& t(r)=t_{o} e^{\frac{-\rho \omega^{2} r^{2}}{2 \sigma}} \\
& \therefore I_{m}=\frac{4 \pi \sigma^{2} t_{o}}{\rho \omega^{4}}
\end{aligned}
$$

3. Energy

$$
E=I_{m} \omega^{2}
$$

Substituting Equation (3) into (4), yields:

$$
E=\frac{t_{o} 2 \pi \sigma^{2}}{\rho \omega^{2}}=\frac{\sigma m}{\rho}
$$

4. Design Stress

Solving Equation (5) for $\sigma_{\text {Design, }}$ yields:

$$
\sigma_{\text {Design }}=\frac{\rho E}{m}
$$


To meet the flywheel design requirements and a positive factor of safety, the following fibers and matrices were considered for the lamina construction due to their high ultimate tensile strength:

\begin{tabular}{|c|c|c|c|c|}
\hline Fiber & $\begin{array}{c}\rho_{\mathrm{f}} \\
\left(\mathrm{Kg} / \mathrm{m}^{3}\right)\end{array}$ & $\mathrm{E}_{\mathrm{f}}(\mathrm{Gpa})$ & $v_{\mathrm{f}}$ & $\mathrm{F}_{\mathrm{ft}}(\mathrm{Mpa})$ \\
\hline $\begin{array}{c}\text { Torray-T1000 } \\
\text { (PAN) }\end{array}$ & 1800 & 294 & 0.2 & 7060 \\
\hline Hexel IM6 (PAN) & 1760 & 279 & 0.2 & 5740 \\
\hline
\end{tabular}

Table 7: Fiber Options

\begin{tabular}{|c|c|c|c|c|}
\hline Matrix & $\rho_{\mathrm{m}}\left(\mathrm{Kg} / \mathrm{m}^{3}\right)$ & $\mathrm{E}_{\mathrm{m}}(\mathrm{Gpa})$ & $v_{\mathrm{m}}$ & $\mathrm{F}_{\mathrm{mt}}(\mathrm{Mpa})$ \\
\hline Epoxy E8552 & 1301 & 4.67 & 0.38 & 100 \\
\hline HDPE & 960 & 1.07 & 0.38 & 220.63 \\
\hline
\end{tabular}

Table 8: Matrix Options

In order to obtain the best $\mathrm{F}_{1 \mathrm{t}}$ of the lamina, the ultimate tensile strength was computed with different volume fractions:

$$
F_{1 t}=F_{f t}\left[V_{f}+\frac{E_{m}}{E_{f}}\left(1-V_{f}\right)\right]
$$

The mechanical properties of the proposed laminas were computed using CADEC, Version 12.0.4864.18178, and were computed using a volume fraction of $70 \%$ fiber to $30 \%$ epoxy. The mechanical properties computed utilizing CADEC were governed by the following equations:

$$
\begin{gathered}
E_{1}=E_{f} V_{f}+E_{m} V_{m} \\
\frac{1}{E_{2}}=\frac{V_{m}}{E_{m}}+\frac{V_{f}}{E_{f}} \\
v_{12}=v_{f} V_{f}+v_{m} V_{m} \\
v_{23}=\text { Obtained ThroughCADEC }
\end{gathered}
$$




$$
\begin{gathered}
G_{12}=G_{m}\left[\frac{\left(1+V_{f}\right)+\left(1-V_{f}\right) G_{m} / G_{f}}{\left(1-V_{f}\right)+\left(1+V_{f}\right) G_{m} / G_{f}}\right] \\
G_{23}=G_{m} \frac{V_{f}+\eta_{4}\left(1-V_{f}\right)}{\eta_{4}\left(1-V_{f}\right)+V_{f} G_{m} / G_{f}} \\
\eta_{4}=\frac{3-4 v_{m}+G_{m} / G_{f}}{4\left(1-v_{m}\right)}
\end{gathered}
$$

\begin{tabular}{|c|c|c|c|c|c|c|}
\hline $\begin{array}{c}\text { Lamina } \\
\text { T1000/E8552 }\end{array}$ & $\begin{array}{c}\mathrm{E}_{1} \\
(\mathrm{Gpa})\end{array}$ & $\mathrm{E}_{2}(\mathrm{Gpa})$ & $v_{12}$ & $v_{23}$ & $\mathrm{G}_{12}(\mathrm{Gpa})$ & $\begin{array}{c}\mathrm{G}_{23} \\
(\mathrm{Gpa})\end{array}$ \\
\hline $\mathrm{IM} 6 / \mathrm{E} 8552$ & 196.700 & 22.760 & 0.246 & 0.532 & 8.909 & 7.823 \\
\hline T1000/HDPE & 206.121 & 5.638 & 0.246 & 0.541 & 2.157 & 1.875 \\
\hline IM6/HDPE & 195.621 & 5.630 & 0.246 & 0.541 & 2.155 & 1.873 \\
\hline
\end{tabular}

Table 9: Proposed Laminas Mechanical Properties

Using the mechanical properties for the proposed laminas in table (9), two laminates were constructed for the evaluation of the flywheel design, [0/45/$45 / 90]_{\mathrm{s}}$, and $[0 / 60 /-60 / 0]_{\mathrm{s}}$. Figure (4), illustrates the methodology behind the analysis of the laminates compliance to the design requirements.

The reduced stiffness matrix [Q] and the intralaminar stiffness matrix [Q*] in lamina coordinates were computed as follows: 


$$
\begin{aligned}
& {[Q]=\left[\begin{array}{ccc}
Q_{11} & Q_{12} & 0 \\
Q_{21} & Q_{22} & 0 \\
0 & 0 & Q_{66}
\end{array}\right]} \\
& {\left[Q^{*}\right]=\left[\begin{array}{cc}
Q^{*} & 0 \\
0 & Q^{*}
\end{array}\right]} \\
& Q_{11}=\frac{E_{1}}{\Delta} \\
& Q_{12}=Q_{21}=\frac{v_{12} E_{2}}{\Delta} \\
& Q_{22}=\frac{E_{2}}{\Delta} \\
& Q_{66}=G_{12} \\
& Q^{*}{ }_{44}=G_{23} \\
& Q^{*}{ }_{55}=G_{13} \\
& \Delta=1-v_{12} v_{21}
\end{aligned}
$$

Once the reduced stiffness matrix and the intralaminar stiffness matrix have been computed, equation (14) along with the transformation matrix equation (15) using the applicable $\Theta$.

$$
\begin{aligned}
& {[T(\theta)]=\left[\begin{array}{ccc}
m^{2} & n^{2} & 2 m n \\
n^{2} & m^{2} & -2 m n \\
-m n & m n & m^{2}-n^{2}
\end{array}\right]} \\
& m=\cos (\theta) \\
& n=\sin (\theta) \\
& \quad[\bar{Q}]=[T]^{-1}[Q][T]^{-T}
\end{aligned}
$$

Using equation (16), equation (17) is constructed yielding the ABDH Matrix: 


$$
\begin{aligned}
& A_{i j}=\sum_{k=1}^{N}\left(\bar{Q}_{i j}\right)_{k}\left(z_{k}-z_{k-1}\right)=\sum_{k=1}^{N}\left(\bar{Q}_{i j}\right)_{k} t_{k} ; i, j=1,2,6 \\
& B_{i j}=\frac{1}{2} \sum_{k=1}^{N}\left(\bar{Q}_{i j}\right)_{k}\left(z_{k}^{2}-z_{k-1}^{2}\right)=\sum_{k=1}^{N}\left(\bar{Q}_{i j}\right)_{k} t_{k} \overline{z_{k}} ; i, j=1,2,6 \\
& D_{i j}=\frac{1}{3} \sum_{k=1}^{N}\left(\bar{Q}_{i j}\right)_{k}\left(z_{k}^{3}-z_{k-1}^{3}\right)=\sum_{k=1}^{N}\left(\bar{Q}_{i j}\right)_{k}\left(t_{k} \overline{z_{k}^{2}}+\frac{t_{k}^{3}}{12}\right) ; i, j=1,2,6 \\
& H_{i j}=\frac{5}{4} \sum_{k=1}^{N}\left(\overline{Q_{i j}^{*}}\right)\left[t_{k}-\frac{4}{t^{2}}\left(t_{k} \overline{z_{k}^{2}}+\frac{t_{k}^{3}}{12}\right)\right] ; i, j=4,5
\end{aligned}
$$

Utilizing equation (17), the plate stiffness Matrices $[A B D]$ and $[H]$ are constructed as follows:

$$
\begin{aligned}
& {[A B D]=\left[\begin{array}{llllll}
A_{11} & A_{12} & A_{16} & B_{11} & B_{12} & B_{16} \\
A_{12} & A_{22} & A_{26} & B_{12} & B_{22} & B_{26} \\
A_{16} & A_{26} & A_{66} & B_{16} & B_{26} & B_{66} \\
B_{11} & B_{12} & B_{16} & D_{11} & D_{12} & D_{16} \\
B_{12} & B_{22} & B_{26} & D_{12} & D_{22} & D_{26} \\
B_{16} & B_{26} & B_{66} & D_{16} & D_{26} & D_{66}
\end{array}\right]} \\
& {[H]=\left[\begin{array}{ll}
H_{44} & H_{45} \\
H_{45} & H_{55}
\end{array}\right]}
\end{aligned}
$$

Inversing equation (18) yields the plate compliance matrices $[\alpha \beta \delta]$ and $[\mathrm{h}]$, equation (19)

$$
\begin{gathered}
{[\alpha \beta \delta]=\left[\begin{array}{llllll}
\alpha_{11} & \alpha_{12} & \alpha_{16} & \beta_{11} & \beta_{12} & \beta_{16} \\
\alpha_{12} & \alpha_{22} & \alpha_{26} & \beta_{12} & \beta_{22} & \beta_{26} \\
\alpha_{16} & \alpha_{26} & \alpha_{66} & \beta_{16} & \beta_{26} & \beta_{66} \\
\beta_{11} & \beta_{12} & \beta_{16} & \delta_{11} & \delta_{12} & \delta_{16} \\
\beta_{12} & \beta_{22} & \beta_{26} & \delta_{12} & \delta_{22} & \delta_{26} \\
\beta_{16} & \beta_{26} & \beta_{66} & \delta_{16} & \delta_{26} & \delta_{66}
\end{array}\right]} \\
{[h]=\left[\begin{array}{ll}
h_{44} & h_{45} \\
h_{45} & h_{55}
\end{array}\right]}
\end{gathered}
$$


The next step of the analysis will be the computation of the membrane forces. Based on the flywheel design and loading conditions, only membrane forces in the $\mathrm{X}$ any $\mathrm{Y}$ axis will be considered, moments and transverse shear loading will be set equal to zero $\left(M_{x}=M_{y}=M_{x y}=V_{x}=V_{y}=0\right)$.

Using equation (6), the design stress was computed for each of the proposed laminates (see Table 4). Subsequently, the membrane forces were computed as follows:

$$
\left\{\begin{array}{l}
N_{x} \\
N_{y} \\
N_{x y}
\end{array}\right\}=\left\{\begin{array}{c}
\sigma_{\text {Design }} t_{o} \\
\sigma_{\text {Design }} t_{o} \\
0
\end{array}\right\}
$$

Combining equation (18) and (20), the midsurface strains were computed as follows:

$$
\left\{\begin{array}{c}
N x \\
N y \\
N x y \\
M x \\
M y \\
M x y
\end{array}\right\}=\left[\begin{array}{llllll}
A_{11} & A_{12} & A_{16} & B_{11} & B_{12} & B_{16} \\
A_{12} & A_{22} & A_{26} & B_{12} & B_{22} & B_{26} \\
A_{16} & A_{26} & A_{66} & B_{16} & B_{26} & B_{66} \\
B_{11} & B_{12} & B_{16} & D_{11} & D_{12} & D_{16} \\
B_{12} & B_{22} & B_{26} & D_{12} & D_{22} & D_{26} \\
B_{16} & B_{26} & B_{66} & D_{16} & D_{26} & D_{66}
\end{array}\right]\left\{\begin{array}{c}
\varepsilon_{x}^{o} \\
\varepsilon_{y}^{o} \\
\gamma_{x y}^{0} \\
\kappa_{x} \\
\kappa_{y} \\
\kappa_{x y}
\end{array}\right\}
$$

Next step is to evaluate the laminates using the two proposed lamina orientations, $[0 / 45 /-45 / 90]_{\mathrm{s}}$, and $[0 / 60 /-60 / 0]_{\mathrm{s}}$, and compute the minimum $\mathrm{R}_{\mathrm{FPF}}$ value to attain the FoS and ensure the structural integrity of the wheel. The $\mathrm{R}_{\mathrm{FPF}}$ was computed utilizing the Maximum Stress Criterion, and was attained from CADEC along with equations (7) through (21). For a complete set of solutions for each of the proposed laminates using the two lamina orientations herein.

\begin{tabular}{|c|c|c|c|c|c|c|c|}
\hline \multirow{2}{*}{ Orientation } & Lamina & $\begin{array}{l}\sigma_{\text {Design }} \\
(\mathrm{MPa})\end{array}$ & $\mathrm{t}_{\mathrm{o}}(\mathrm{m})$ & $\mathrm{N}_{\mathrm{x}}(\mathrm{N} / \mathrm{mm})$ & $\mathrm{N}_{\mathrm{y}}(\mathrm{N} / \mathrm{mm})$ & $\begin{array}{l}\mathrm{N}_{\mathrm{xy}} \\
(\mathrm{N} / \mathrm{m} \\
\mathrm{m})\end{array}$ & $\mathrm{R}_{\mathrm{FPF}}$ \\
\hline \multirow{2}{*}[0/60/-60/0]{$_{\mathrm{s}}$} & $\mathrm{T} 1000 / \mathrm{E} 8552$ & 1650.3 & 0.051822 & 85521.2056 & 85521.2056 & 0 & 0.2 \\
\cline { 2 - 9 } & $\mathrm{IM} 6 / \mathrm{E} 8552$ & 1622.3 & 0.052716 & 85521.2056 & 85521.2056 & 0 & 0.2 \\
\cline { 2 - 9 } & $\mathrm{T} 1000 / \mathrm{HDPE}$ & 1548.0 & 0.055246 & 85521.2056 & 85521.2056 & 0 & 1.3 \\
\hline
\end{tabular}

40

www.Jutq.utq.edu.iq Web Site of the Journal 


\begin{tabular}{|c|c|c|c|c|c|c|c|} 
& IM6/HDPE & 1520.0 & 0.056264 & 85521.2056 & 85521.2056 & 0 & 1.1 \\
\hline \multirow{3}{*}{$\begin{array}{c}{[0 / 45 /-} \\
45 / 90]_{\mathrm{s}}\end{array}$} & T1000/E8552 & 1650.3 & 0.051822 & 85521.2056 & 85521.2056 & 0 & 0.2 \\
\cline { 2 - 9 } & IM6/E8552 & 1622.3 & 0.052716 & 85521.2056 & 85521.2056 & 0 & 0.2 \\
\cline { 2 - 9 } & T1000/HDPE & 1548.0 & 0.055246 & 85521.2056 & 85521.2056 & 0 & 1.7 \\
\cline { 2 - 9 } & IM6/HDPE & 1520.0 & 0.056264 & 85521.2056 & 85521.2056 & 0 & 1.4 \\
\hline
\end{tabular}

Table 10: Proposed Lamina $\mathbf{R}_{\mathrm{FPF}}$ Comparison

\section{CONCLUSION}

For verification of the design, an FEA was performed on the flywheel design for the configurations with the maximum $\mathrm{R}_{\mathrm{FPF}}$ in table (10). The analysis was performed using Solidworks Simulation 2012. In order to be able to conduct the FEA, the mechanical properties of the laminate were converted from orthotropic to isotropic (In-Plane) so that the values can be loaded into the software, this process was as follows:

$$
\begin{aligned}
& E_{x}=\frac{1}{t \alpha_{11}}=\frac{A_{11} A_{22}-A_{12}^{2}}{t A_{22}} \\
& E_{y}=\frac{1}{t \alpha_{22}}=\frac{A_{11} A_{22}-A_{12}^{2}}{t A_{11}} \\
& G_{x y}=\frac{1}{t \alpha_{66}}=\frac{A_{66}}{t} \\
& v_{x y}=-\frac{\alpha_{12}}{\alpha_{11}}=\frac{A_{12}}{A_{22}}
\end{aligned}
$$

It was also important to compute the ultimate strength of the laminate to attain the FoS from the FEM and compare it to the value from the aforementioned composite analysis of the lamina utilizing the FPF strength factor (see Table 12).

$$
\sigma_{U L T}=\sigma_{\text {Design }} R_{F P F}
$$

\begin{tabular}{|c|c|c|c|c|c|c|}
\hline Orientation & Lamina & $\mathrm{t}_{\mathrm{o}}(\mathrm{m})$ & $\mathrm{E}_{\mathrm{x}}(\mathrm{Gpa})$ & $\mathrm{E}_{\mathrm{y}}(\mathrm{Gpa})$ & $\mathrm{G}_{\mathrm{xy}}(\mathrm{Gpa})$ & $v_{\mathrm{xy}}$ \\
\hline \multirow{2}{*}[0/45/-45/90]{$_{\mathrm{s}}$} & $\mathrm{T} 1000 / \mathrm{HDPE}$ & 0.055246 & 72.352 & 72.352 & 27.270 & 0.327 \\
\cline { 2 - 7 } & $\mathrm{IM} 6 / \mathrm{HDPE}$ & 0.056264 & 68.848 & 68.848 & 25.956 & 0.326 \\
\hline
\end{tabular}

Table 11: Isotropic Laminate Mechanical Properties

41

www.Jutq.utq.edu.iq Web Site of the Journal 
Using the values given in table (11), three FEAs were performed:

1. Flywheel, T1000/HDPE

2. Flywheel, IM6/HDPE

3. Flywheel, 2800 Maraging Steel Alloy (Not Part of Table 11)

All three translational DOFs were constrained around the circumference of the shaft edge, the load was applied as a centrifugal load about the flywheel shaft (see Figure 6).

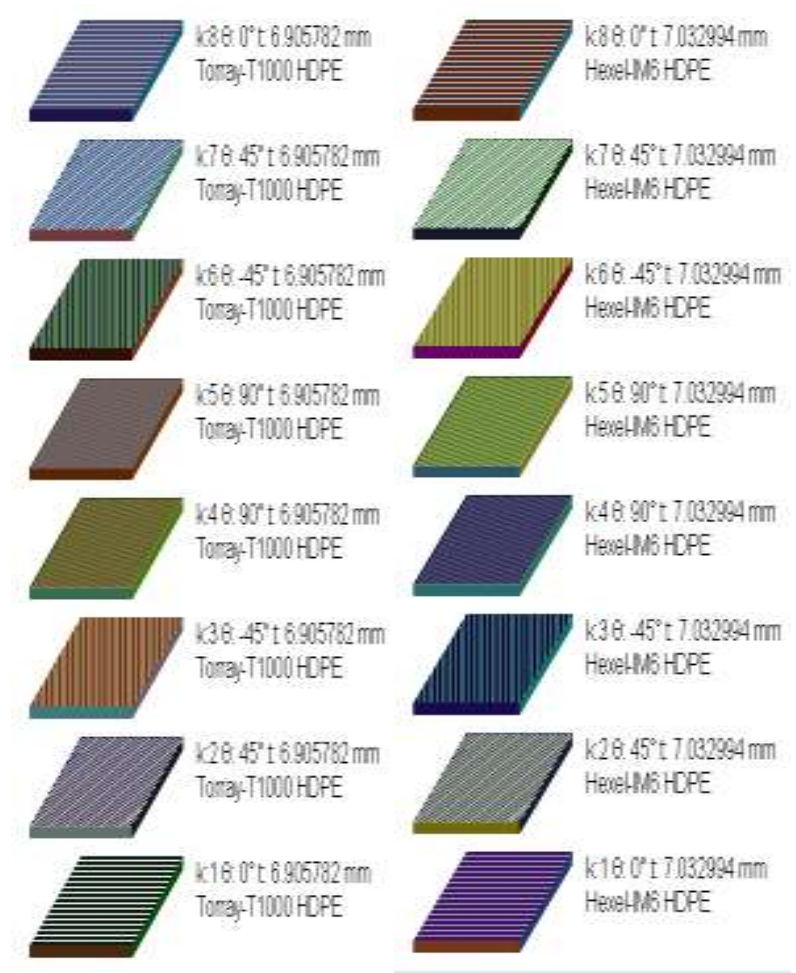

Figure 2: Selected Laminates Stacking Sequence 

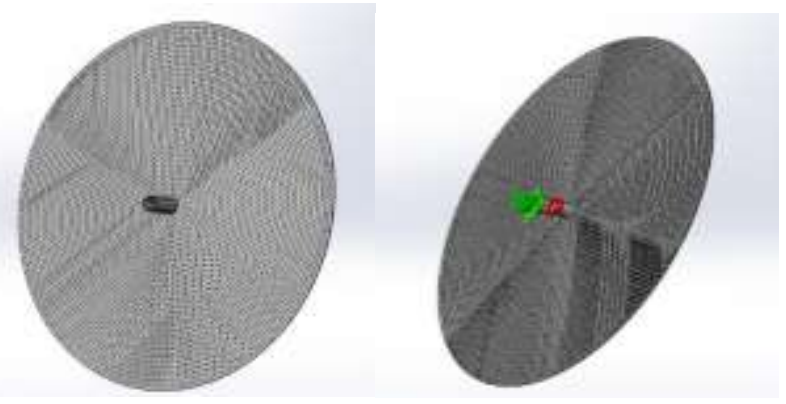

Figure 3: Flywheel FEA Mesh

\begin{tabular}{|c|c|c|c|c|c|}
\hline Configuration & $\sigma_{\text {MAX-FEA }}(\mathrm{Mpa})$ & $\sigma_{\text {ULT }}(\mathrm{Mpa})$ & Mass $(\mathrm{Kg})$ & Energy (M Joules) & $\begin{array}{c}\text { FoS }_{\mathrm{F}} \\
\text { EA }\end{array}$ \\
\hline T1000/HDPE & 1431.14 & 2558.84 & 10.00 & 10.00 & 1.79 \\
\hline IM6/HDPE & 1436.20 & 2083.92 & 10.00 & 10.00 & 1.45 \\
\hline 2800 Maraging Steel & 5265.90 & 2617.00 & 6.69 & 10.00 & 0.50 \\
\hline
\end{tabular}

Table 12: FEA Results Summary

\begin{tabular}{|c|c|c|}
\hline Configuration & FoS $_{\text {FEA }}$ & $\mathrm{R}_{\mathrm{FPF}}$ \\
\hline T1000/HDPE & 1.8 & 1.7 \\
\hline IM6/HDPE & 1.5 & 1.4 \\
\hline 2800 Maraging Steel & 0.5 & N/A \\
\hline
\end{tabular}

Table 13: FEA FoS vs Composite Analysis (CADEC) $R_{\text {FPF }}$

\begin{tabular}{|c|c|c|c|c|}
\hline Configuration & Cost $(\$) / \mathrm{Kg}$ & Mass $(\mathrm{Kg})$ & Flywheel Cost $(\$)$ & FoS $_{\text {FEA }}$ \\
\hline T1000/HDPE & 400 & 10.00 & 4000 & 1.79 \\
\hline IM6/HDPE & 110 & 10.00 & 1100 & 1.45 \\
\hline 2800 Maraging Steel & 4 & 6.69 & 26.67 & 0.50 \\
\hline
\end{tabular}

Table 14: Flywheel Material Option Price Comparison

As illustrated in table (14), the composite options are significantly higher than that of the alloy option. However, given the design requirements, it is evident that composites dominate in the area of stress and FoS. In an application where the flywheel is used on an automobile, it is critical to have a strong and safe system. Usually an FoS of two (2) is required, but with the current composite material available in today's market and the data available through the text book, the best material yielding the highest FoS are T1000/HDPS, and IM6/HDPE, with a fiber volume fraction of $70 \%$. 
Through the formula for rotational kinetic energy (4) and a number of additional substitutions, it can be found that the energy stored by the infiniteradius flywheel is:

$$
E_{i n f}=t_{0} \frac{2 \pi \sigma^{2}}{\rho \omega^{2}}=\frac{\sigma}{\rho} m
$$

This result places an upper bound on energy based solely on material specific strength, and the mass of the flywheel. This is why specific strength is so important with the material of an energy storage flywheel.

This flywheel is a truncated case of the Stodola flywheel. Truncating the flywheel to a finite diameter decreases mass, inertia and stored energy slightly, but this was deemed to be negligible at the truncation radius chosen and thus these formulae were used as a close approximation of our flywheel in our analytical model.

Based off the assigned design criteria (mass, RPM, and stored energy all constrained), it was decided to optimize factor of safety by reducing design stress as far as possible.

$$
\begin{gathered}
\sigma_{\text {nominal }}=\frac{\rho E}{m} \\
t_{0}=\frac{m^{2} \omega^{2}}{2 \pi \rho E} \\
t(r)=\frac{m^{2} \omega^{2}}{2 \pi \rho E} e^{\frac{-m \omega^{2}}{2 E} r^{2}}
\end{gathered}
$$

For the composite materials, once these figures were obtained, a segment of the quasi-isotropic laminate was modeled in CADEC and the virtual shell 
load $\left(N_{x}=N_{y}=t^{*} \sigma_{\text {nominal }}\right)$ was simulated. The R-factors obtained from the CADEC simulation was recorded (Table 13). These confirmed that the idealized Stodola design, using both selected composites, could store the full $10 \mathrm{MJ}$ of energy without failing.

For the alloy flywheel, a corresponding analytical determination was made by comparing the nominal operating stress of the flywheel obtained from the excel spreadsheet to the yield strength of the alloy. This calculation indicated that an alloy flywheel would NOT meet the required design criteria, as a factor of safety of only 0.327 was obtained.

Next, each flywheel was modeled in Solidworks using an equation-driven curve truncated by a radiuses edge. From each simulation, plots of Von Mises stress (Figures 7-9) and a minimum factor of safety number (Table 13) was obtained. These generally agreed with the analytical results obtained from the Excel spreadsheet and the R-factors from the CADEC shell load simulation. Though notably, it was apparent that radial stress near the edge of a truncated Stodola was lower than the stress of an ideal infinite-radius Stodola, as would be expected.

\section{REFERENCES}

1. Satish V. Kulkarni, Richard G. Stone. "Rimmed and Edge Thickened Stodola-Shaped Flywheel.” US Patent no. 4408500. Filed Sept. 1980. Web: http://www.google.com/patents/US4408500

2. Jerome Tzeng, Ryan Emerson, and Paul Moy. "Composite Flywheel Development for Energy Storage." Army Research Laboratory, January 2005. Web: $\quad$ http://www.dtic.mil/cgibin/GetTRDoc?AD=ADA431734.

3. G.R. Kress. "Shape Optimization of a Flywheel." Structural and Multidisciplinary Optimization. Volume 19, Issue 1. Springer- 
Verlag, March2000.Web: http://link.springer.com/content/pdf/10.1007\%2Fs001580050087.pdf

4. Prof. K.Gopinath \& Prof. M.M.Mayuram, Indian Institute Technology "Flywheel."

5. "Optimal Design of a Hybrid Composite Flywheel with a Permanent Magnet Rotor." Journal of Composite Materials. August 1999. Web: http://jcm.sagepub.com/content/33/16/1544.full.pdf+html.

6. Bjo"rn Bolund, Hans Bernhoff, Mats Leijon. "Flywheel energy and power storage systems." $2007 . \quad$ Web: http://www.inference.phy.cam.ac.uk/sustainable/refs/storage/Flywhe el.pdf.

7. "MatWeb Property Search - Metal." MatWeb material database. Matweb.com.

Web: http://www.matweb.com/search/PropertySearch.aspx

8. Barbero, Ever J. "Introduction to Composite Materials Design", $2^{\text {nd }}$ Edition, 2011 CRC Press Taylor \& Francis Group, FL

9 .Rathod Balasaheb S, Satish. M. Rajmane. "A Case Study on Design of a Flywheel for Punching Press Operation." International Journal of Engineering and Advanced Technology (IJEAT). Volume 3, Issue 4. April 2014. 